\title{
A maturity model for the servitization of product-centric companies
}

Federico Adrodegari and Nicola Saccani

\author{
Department of Mechanical and Industrial Engineering, University of Brescia, \\ Brescia, Italy
}

\begin{abstract}
Purpose - The purpose of this paper is to contribute to the understanding of the servitization phenomenon of product-centric companies, by identifying the resources, capabilities and organizational aspects needed to successfully deploy a servitized business model (BM).

Design/methodology/approach - By adopting a literature-based approach, this paper develops a servitization maturity model (SeMM) aimed at assessing and positioning companies in the servitization journey. The paper also illustrates the model application to two small and medium-sized enterprises (SMEs), a machinery and a forklift truck company.

Findings - The SeMM identifies a set of 85 critical requirements that are used to evaluate the servitization level of product-centric companies, through a specific five-stage measurement scale. The requirements are categorized into: five maturity dimensions (organizational approach, process management, performance management, tools, capabilities) and nine BM Canvas components. The empirical application exemplifies how the SeMM can support managers in identifying and bridging the gaps in their servitization journey.

Originality/value - The SeMM adopts an original bi-dimensional approach and provides an operationalization of the servitization process through the identification of specific critical requirements framed on established BM and maturity dimensions taken from the literature. Moreover, the model responds to a call for research to develop practitioner-oriented tools and guidelines to support the servitization process, in particular for SMEs, and to the need to go beyond to measures of servitization based on indicators about number of services offered or their turnover.
\end{abstract}

Keywords Servitization, Case studies, Service operations, SMEs, Maturity model

Paper type Research paper

\section{Introduction}

To increase revenues and build sustainable competitive advantage, product-centric companies are increasingly undergoing servitization (Neely, 2008; Baines et al., 2009). To be successful in this transformation, they should redesign their business model (BM) (Forkmann et al., 2017; Kowalkowski et al., 2017; Raddats et al., 2019). However, product-centric companies undertaking servitization face several challenges (Alghisi and Saccani, 2015; Zhang and Banerji, 2017), and this transition remains a complex matter (Reim et al., 2015; Martinez et al., 2017), especially for small and medium-sized enterprises (SMEs) (Kowalkowski et al., 2013). In fact, servitization research has devoted limited attention to comprehensively analyzing the elements that support this BM reconfiguration (Adrodegari and Saccani, 2017; Forkmann et al., 2017). Moreover, empirical evidence mainly concerns large multinational companies, while SMEs attempts to servitize are not much investigated (Adrodegari et al., 2018; de Jesus Pacheco et al., 2019). Despite the considerable amount of literature on servitization, moreover, a lack of studies has been pointed out about describing and prescribing how to servitize a product-centric firm

(c) Federico Adrodegari and Nicola Saccani. Published by Emerald Publishing Limited. This article is published under the Creative Commons Attribution (CC BY 4.0) licence. Anyone may reproduce, distribute, translate and create derivative works of this article (for both commercial and non-commercial purposes), subject to full attribution to the original publication and authors. The full terms of this licence may be seen at http://creativecommons.org/licences/by/4.0/legalcode

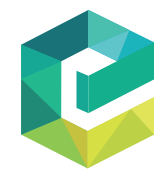

Journal of Manufacturing Technology Managemen Vol. 31 No. 4,2020 pp. $775-797$ 
JMTM 31,4
(Baines et al., 2017). This paper adopts the maturity model (MM) approach as a mean to fill this gap. More specifically, it develops a servitization MM (SeMM) that characterizes servitization maturity levels, assessing and positioning companies undergoing the transformation. The SeMM is built on established BM and maturity dimensions, operationalized through specific items (critical requirements). Moreover, based on two case studies, the paper shows how the SeMM can be used in practice to support assessment and change actions in SMEs.

The paper is structured as follows. The next section provides a literature background, Section 3 describes the research methodology, Section 4 describes the SeMM and Section 5, the empirical application. Finally, Section 6 draws some concluding remarks.

\section{Theoretical background}

\subsection{The servitization of product-centric companies}

An increasing number of product-centric companies are shifting from selling products to providing solutions to gain competitive advantage, increase revenues, margins, customer satisfaction and retention (Oliva and Kallenberg, 2003; Neely, 2008). Such transition, named servitization, can be conceptualized as "a change process whereby a manufacturing company deliberately or in an emergent fashion introduces service elements in its BM" (Brax and Visintin, 2017 p. 18). The BM perspective is, therefore, central to characterizing servitization (Adrodegariand Saccani, 2017; Baines et al., 2017; Forkmann et al., 2017; Suppatvech et al., 2019; Raddats et al., 2019), as it describes how value is created, delivered and captured (Teece, 2010). Several product-centric companies are, therefore, innovating their BM either by adding advanced services to their product offerings or delivering products "as services," selling their usage or performance (Baines and Lightfoot, 2013; Ayala et al., 2017; Martinez et al., 2017; Suppatvech et al., 2019).

However, this transformation requires fundamental changes in the firm's structure, culture and competencies, in the way value is delivered and relationships with customers and stakeholders are managed (Martinez et al., 2010; Martinez, 2017). Therefore, servitizing companies may incur the so-called "service paradox" and not reach the expected benefits (Gebauer et al., 2005) while they are exposed to greater internal and environmental risks that may prevent achieving the financial and economic outcomes posited by the servitization literature (Neely, 2008; Benedettini et al., 2015).

The service transition, thus, remains a complex matter for both scholars and practitioners, in particular from SMEs (Tukker, 2015; Kowalkowski et al., 2017). In fact, it is acknowledged that undertaking a servitization path is less common in SMEs than in large firms (Neely, 2008), and that SMEs usually do not possess the resources or the experience to successfully undertake the servitization journey (Kowalkowski et al., 2013; Clegg et al., 2017). However, only few prior studies address servitization in SMEs (e.g. Coreynen et al., 2017; Valtakoski and Witell, 2018). Research has, therefore, been called to provide models and guidelines aimed to describe and prescribe how to servitize a product-centric firm (Adrodegari et al., 2017; Baines et al., 2017).

MMs appear as suitable tools to fill this gap, as they allow assessing the current maturity of a company in servitization and identifying the main actions needed to successfully deploy a servitized BM, and their descriptive and diagnostic role can be particularly useful to SMEs.

\subsection{Maturity models}

The seminal capability MM (CMM), "a framework representing a path of improvements recommended for software organizations that want to increase their software process capability" (Paulk et al., 1993 p. 27), was developed for the information systems sector by the Software Engineering Institute. MMs have then been developed for several other domains such as business process management (Roglinger et al., 2012), inventory 
management (Niemi et al., 2009), supply chain management (Lockamy and McCormack, 2004), new product development (Fraser et al., 2002), R\&D projects (Berg et al., 2002), project management (Cooke-Davies and Arzymano, 2003), quality management (Yoo et al., 2006), sustainability (Pigosso and McAloone, 2016; Machado et al., 2017; Correia et al., 2017), service innovation (Rapaccini et al., 2013) and service management (Neff et al., 2014; Alvarez et al., 2015).

MMs represent theories about how organizations evolve in a stage-by-stage manner along an anticipated, desired or logical path (Röglinger et al., 2012). MMs are, therefore, adequate for complex topics because the sequence of levels and their requirements, tracing multiple objectives and practices, can gradually lead the company through an improvement process (Wendler, 2012; Van Looy et al., 2014; Machado et al., 2017). In particular, MMs may have three different purposes (de Bruin et al., 2005): descriptive (diagnostic tools to assess the current capabilities of a company), prescriptive (identify desirable maturity levels and provide guidelines and improvement measures) and comparative (internal or external benchmarking).

Given their limited resources and experience, SMEs would particularly benefit from an assessment of their current situation and emergent gaps that can be provided by MMs (Mittal et al., 2018). Therefore, the MM approach appears suitable to address both the gaps about the lack of studies describing and prescribing how to servitize a product-centric firm (Baines et al., 2017) and the limited attention to the issues faced by SMEs in the servitization journey.

\subsection{Maturity models for the service domain in product-centric contexts}

Despite the fact that seminal works suggest that product-centric firms gradually shift along a product-service continuum (Oliva and Kallenberg, 2003; Martinez et al., 2010; Baines and Lightfoot, 2013), a structured effort toward a detailed characterization of servitization stages has not been carried out until recently (Lütjen et al., 2017). It is not surprising, therefore, that few MMs concerning the service business in product-centric companies are found in the literature. They are summarized in Table I.

Wikström et al. (2009) analyze the changes in project-based firms as they move from pure equipment-suppliers to being also service providers. Rapaccini et al. (2013) propose a service development (NSD) MM for product-centric firms built upon the following dimensions: the management of processes and projects; the use of specific resources, skills and tools; the involvement of customers, suppliers and other stakeholders; and the adoption of performance management systems. Jin et al. (2014), similarly, define a set of NSD success factors and group them into dimensions, namely: strategy management, process formalization, knowledge management and customer involvement. The four-stage product-centric service MM by Li et al. (2014) considers four dimensions: sales profit source, service business composition, service process quality and service infrastructure. Neff et al. (2014) developed a MM for the heavy equipment manufacturing industry to assess the information systems support to the product service system (PSS). Their MM, therefore, focuses on information technology as an enabler of servitization and evaluates the following key dimensions: performance measurement of industrial service, installed base management, mobile support for the service workforce, integration of service and product data and data quality assurance. Pigosso and McAloone (2016) applied the five-level Ecodesign MM to support companies in the development of sustainable PSSs. Finally, Alvarez et al. (2015) see servitization as an evolutionary process based on the relationships among players in the value chain. Their MM analyzes four key dimensions: market, network, customer and internal. Only the last two papers mentioned are close to the objective of this study, i.e. to assess the servitization maturity of a company. However, Pigosso and McAloone (2016) focus solely on the environmental sustainability aspect, while the MM by Alvarez et al. (2015) does not support the identification of the main weaknesses and actions to be deployed so that little prescriptive value could be obtained from the model. Moreover, it does not adopt a BM perspective. 
JMTM 31,4

\begin{tabular}{lllll} 
Author & Topic & Dimensions evaluated & Maturity levels & $\begin{array}{l}\text { Empirical } \\
\text { application }\end{array}$ \\
\hline $\begin{array}{l}\text { Wikström } \\
\text { et al. (2009) }\end{array}$ & $\begin{array}{l}\text { Service } \\
\text { provision }\end{array}$ & $\begin{array}{l}\text { Value creation, mental } \\
\text { process, organization, key } \\
\text { process, culture, customer, } \\
\text { priority, main offering, }\end{array}$ & $\begin{array}{l}\text { Goods dominant logic, } \\
\text { customer-centric logic, } \\
\text { business-dominant logic }\end{array}$ & Yes \\
& & and &
\end{tabular}

\section{8}

\section{Rapaccini New service et al. (2013) development}

Li et al. (2014)

Service management

$\begin{array}{ll}\text { Jin } \text { et al. } & \text { New service } \\ \text { (2014) } & \text { development }\end{array}$

Neff et al. Information (2014) system for PSS

Table I.

Review of maturity models in the literature addressing the service domain. (2015)

Pigosso and McAloone (2016) priority, main offering, approach to personnel, sales bias

Organizational approach, resources, customers, suppliers and other stakeholders, performance management

Sales profit sources, service business composition, service process quality, service infrastructure

Strategy management, process formalization, knowledge management, customer involvement

Performance measurement of industrial service, installed base management, mobile support for the service workforce, integration of service and product data, data quality assurance

Alvarez et al. Servitization Market, network, customer, internal

Sustainable PSS PSS development
Initial stage, repeatable, Yes defined, managed, optimized

Basic services, initial stage Yes for value-added services, the growth stage for valueadded services, the maturity stage for valueadded services

Five maturity level for each No dimension

Rudimentary spare parts Yes service, reactive maintenance service, predictive maintenance service, performance contracting service, managing the customer's operations

Prospection, initiation, Yes consolidation, specialization Limited, start-up, experienced, expansion, incorporation
Yes

No

\section{Research process and method}

To fill the gaps emerged from the previous analysis, we adopt a three-step research process. First, we carried out a literature review of MMs relevant for this research. We searched the Scopus database for papers published in scientific journals (conferences were excluded), using keywords such as "maturity model," " capability model," "process improvement model," "assessment model," "maturity grid" in combination with "servitization," "solutions" and "PSS." Among the 69 papers identified, 18 were selected and analyzed after reading the title and the abstract. Only seven of them propose a structured MM related to services in product-centric companies: they have been discussed in section 2.3. We then developed the SeMM, described in section 4. It is built on BM and maturity dimensions found in the literature and operationalized through specific "critical requirements" (Alvarez et al., 2015) that characterize servitized BMs. Besides the MMs analyzed in section 2.3 and the literature on MMs mentioned in section 2.2, to develop the 85 critical requirements in our model, we considered the relevant literature on servitization. In particular, we resorted to the reference framework proposed by (Adrodegari et al., 2017) that identified key aspects for the different 
BM components. To point out the requirements, we analyzed (and enriched) the set of literature analyzed in that paper. In the third step of the research, the model was applied to two companies undertaking the servitization journey, as described in section 5 , to ascertain the exhaustiveness and practical applicability of the SeMM.

To enhance the reliability of the data collection and elaboration (Voss et al., 2002), we designed a research protocol where the SeMM requirements represent the list of aspects to be investigated. The application started with a full-day meeting with the top managers belonging to different business functions such as after-sales service, sales and marketing, research and development (R\&D) and information systems. During the workshop, after identifying the business line object of the study and investigating the company BM and servitization journey, we investigated each critical requirement following the research protocol. A second half-day workshop was then carried out in each firm to discuss the results of the SeMM application, point out the relevant gaps and identify the most appropriate improvement actions.

\section{The servitization maturity model (SeMM)}

\subsection{Overview}

The SeMM evaluates the servitization maturity level of product-centric companies through the assessment of a set of critical requirements. As shown in Figure 1, the model adopts a multi-dimensional approach (Pöppelbuß and Röglinger, 2011): we follow a bi-dimensional approach similar to Kindström and Kowalowski (2014) who addressed service innovation and crossed a BM dimension with a capabilities and resources one. In our work, we cross BM components with maturity dimensions. The five maturity dimensions are derived from the review of relevant MMs in literature and are: organizational approach (e.g. Wikström et al., 2009; Rapaccini et al., 2013), management of processes (e.g.: Van Looy, 2014; Tarhan et al., 2016), performance management systems (e.g.: Alvarez et al., 2015), tools (e.g.: Rapaccini et al., 2013; Neff et al., 2014), capabilities (e.g.: Paulk et al., 1993 and others CMM models). For the BM components, instead, we resort to the nine building blocks of the BM Canvas model (Osterwalder and Pigneur, 2010).

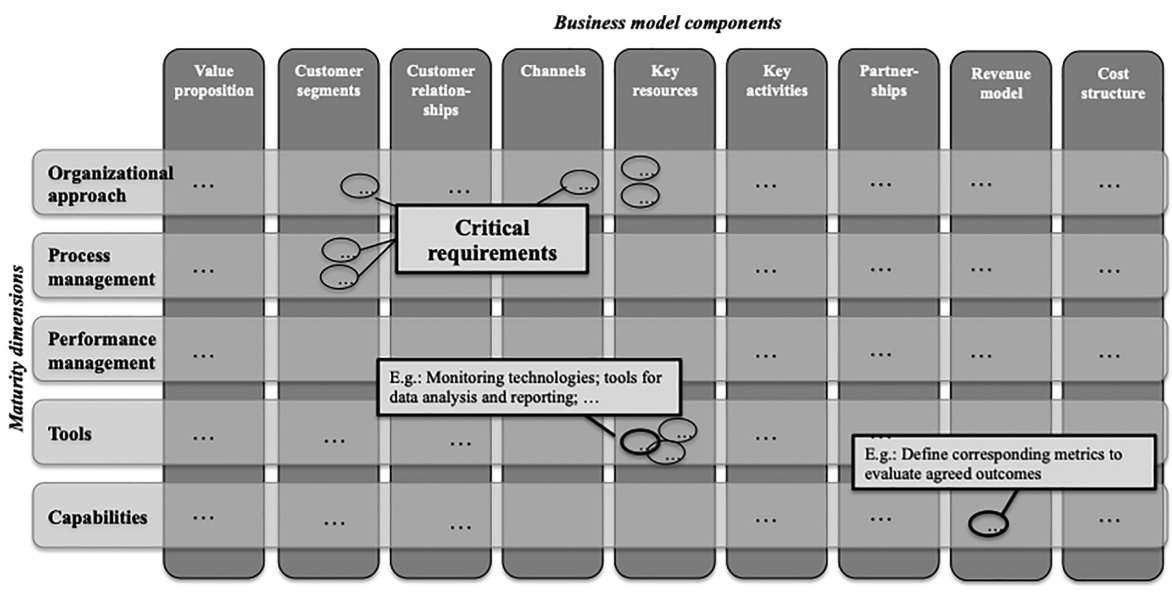

Figure 1. SeMM structure 
JMTM 31,4

780

\subsection{Critical requirements}

Table II reports the 85 critical requirements identified from the literature. In the following, they are described (they appear in italic), grouped according to the nine BM components (Osterwalder and Pigneur, 2010).

4.2.1 Value proposition. In servitized BMs, it becomes crucial to understand the nature of the value that can be generated and delivered to customers. Specific capabilities are needed to this end, such as design-specific value propositions to meet customers' products and service needs (Barquet et al., 2013) and develop new service offerings that create value for the customer (Kindström and Kowalkowski, 2014), which entails extending, repackaging, improving and introducing new lines of service in accordance with market opportunities (Kindström and Kowalkowski, 2009). Specific tools and methods for service value proposition design should be used, such as visualization tools for the co-creation, representation and prototyping of customer-centered services (Kindström, 2010; Keränen and Jalkala, 2013). In particular, new tools and procedures are needed to ease the determination of the value of the new offering. In addition, service portfolio management procedures should be in place (Saul and Gebauer, 2018). Therefore, providing solutions requires a more customer-centric organization (Saul and Gebauer, 2018) and a service logic translation capability to move away from a product-centric culture (Kindström and Kowalkowski, 2014).

4.2.2 Customer relationships. Customer relationships are critical for servitized BMs (e.g. Gebauer et al., 2005; Davies et al., 2007). Therefore, relational skills should be developed in both the sales and after-sales personnel (Kindström et al., 2015). Another important aspect concerns interactions with customers throughout the product lifecycle. It implies the definition of the extent of information sharing. For instance, procedures and practices for managing customer feedbacks on product/service experience need to be implemented to enable the product/service improvement and closer customer relationships (Meier et al., 2010; Kindström and Kowalkowski, 2014). Similarly, information and communications technology (ICT) systems/applications that support the automatization of relationships and collaboration between customers and providers, such as Web-based information tools become fundamental (Reim et al., 2015).

4.2.3 Customer segments. Understanding customer needs is critical to define value propositions that respond to different customer segments (Reim et al., 2015; Storbacka et al., 2013). In this process, required capabilities are understanding the customer's problem and interpret its real needs (Ulaga and Reinartz, 2011) and managing customer's production processes data to gain intimate customer knowledge (Kindström, 2010; Storbacka, 2011). These capabilities represent the basis for providing the most appropriate offer to each customer. Therefore, procedures and practices for assessing customer preferences and needs on product and process-related information but also on service-related information should be established (Kindström, 2010; Storbacka, 2011; Kindström and Kowalkowski, 2014).

4.2.4 Key activities. Servitization often requires developing new activities or redesigning the current ones. Marketing and sales activities, fleet maintenance planning, product retrofit, revamping, disposal and reverse logistic processes (Barquet et al., 2013; Liu et al., 2014) may be (re-)designed. Moreover, companies need the capability to communicate and make tangible the value for the customer of new offerings (Kindström and Kowalkowski, 2009; Reim et al., 2015). To this end, companies should also develop specific sales tools or methods, such as a total cost of ownership model (Meier et al., 2010; Ulaga and Reinartz, 2011; Storbacka et al., 2013). To meet new product and service design requirements, special emphasis should be placed on aligning physical product characteristics with service (Reim et al., 2015): the R\&D function, therefore, should design modular products and components (Mont et al., 2006), in which critical elements are easy to access and to repair (Azarenko et al., 2009), taking into account also the need for disassembly/recycling (Tukker, 2004). Likewise, dedicated teams and roles for new service development should be established (Kindström, 2010; Storbacka, 2011; 


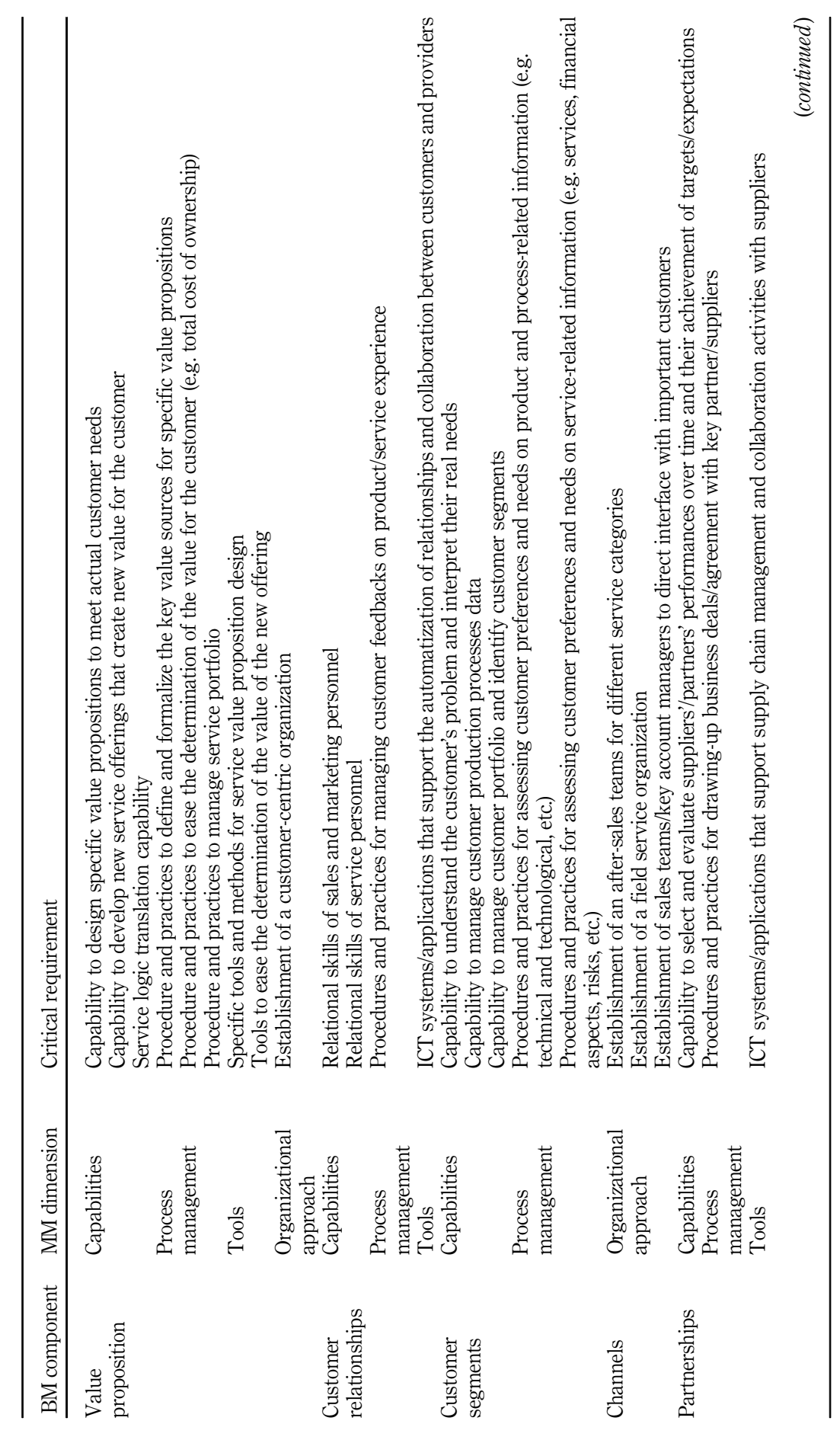

Servitization

781

Table II.

SeMM - critical requirements list 
JMTM
31,4

782

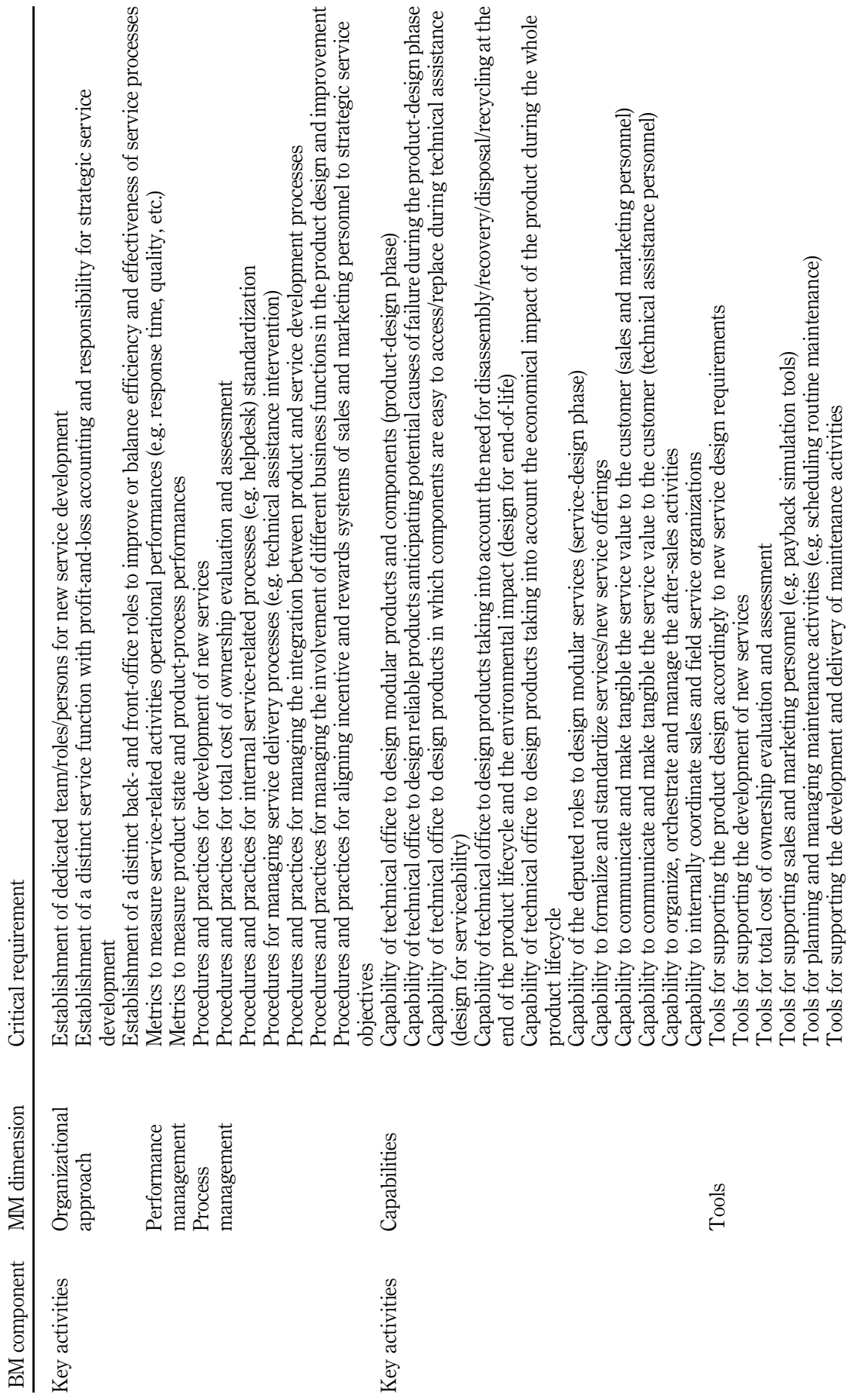

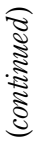

Table II.

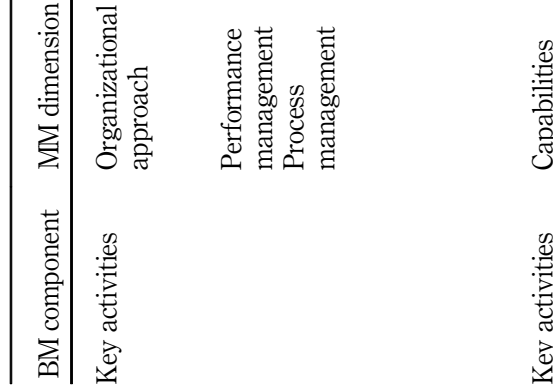




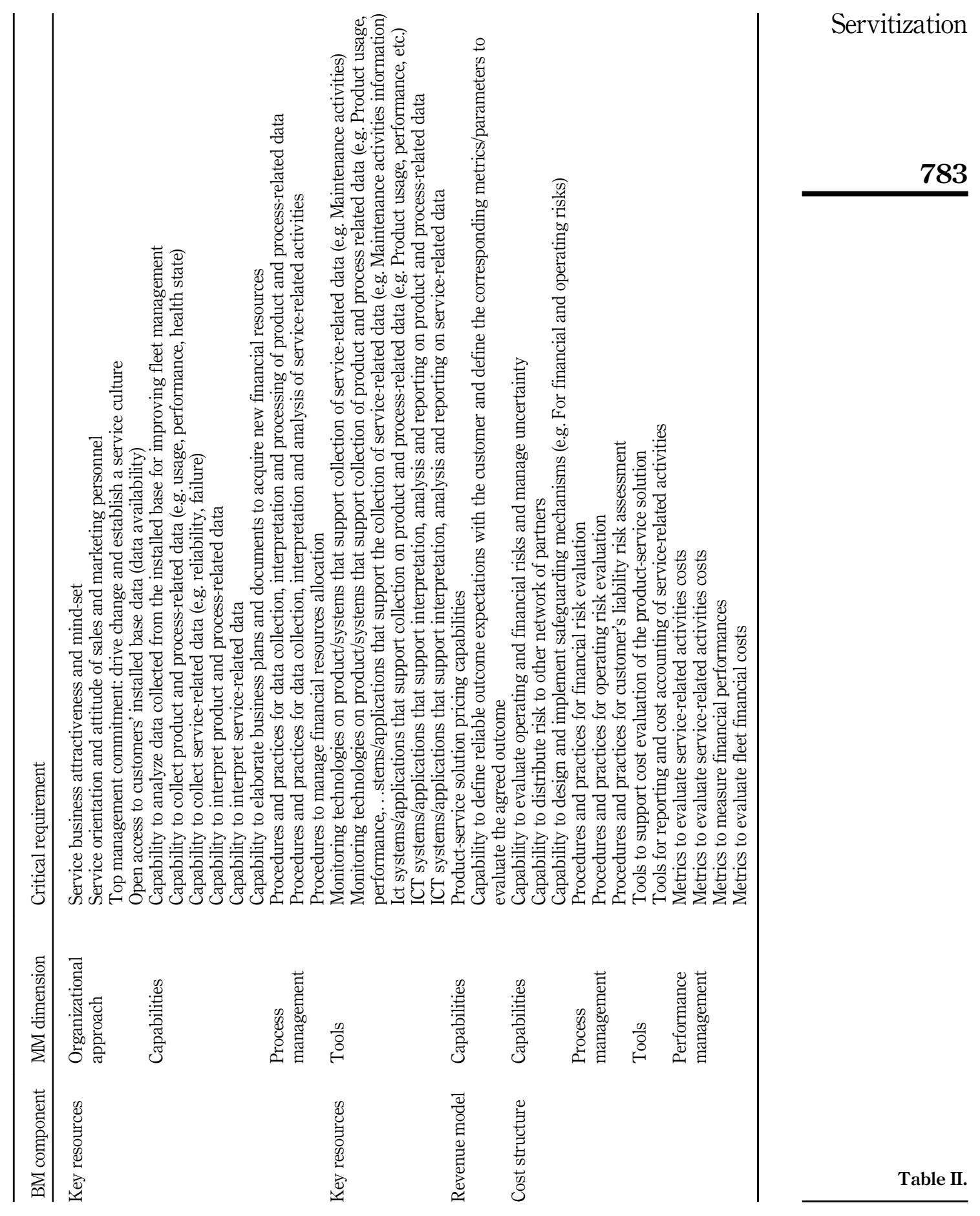


JMTM 31,4

784

Rapaccini et al., 2013), together with procedures for the development of new services (Ulaga and Reinartz, 2011; Storbacka et al., 2013) and service engineering practices for the systematic design and development of services (Meier et al., 2010; Rapaccini et al., 2013). Also, a company needs to formalize and standardize services for a more effective service delivery (Kindström and Kowalkowski, 2014).

The service delivery planning and execution processes are crucial in servitized BMs (Kindström and Kowalkowski, 2009). They should evolve from an uncontrolled and random reaction to a controlled and structured set of actions: to this end, procedures and practices for internal service-related processes standardization along with procedures for managing service delivery processes are required (Storbacka, 2011; Kindström and Kowalkowski, 2014). This evolution may entail also important organizational changes, such as the establishment of a separate service business unit (Oliva and Kallenberg, 2003) and a clear separation between front-office (e.g. technical assistance) and back-office (e.g. help desk) activities. In fact, a dedicated back-office infrastructure enables cost-efficient operations (Kindström and Kowalkowski, 2014). Companies should also implement specific tools to support the service planning, delivery and execution to avoid or minimize troubleshooting processes and also create a knowledge base to further improve service processes (Meier et al., 2010; Kindström and Kowalkowski, 2014).

Since different functions should synergistically operate in service development, planning and execution, the level of interaction and integration among different company functions plays an important role (Nordin and Kowalkowski, 2010; Gebauer and Kowalkowski, 2012). Thus, the inter-functional coordination capability should lead, for example, to increased involvement of the service organization in the sales process (Kowalkowski, 2011). Consequently, procedures and practices for managing these integrations should be implemented.

4.2.5 Key resources. A new corporate culture and top management commitment to the service business) to enhance the service orientation of employees Barquet et al. (2013); Ulaga and Reinartz, 2011. Other critical resource in servitized BMs is the installed base, as it provides critical insights about product operations and valuable customer knowledge (Ulaga and Reinartz, 2011), and the related monitoring technologies (Ardolino et al., 2018). Therefore, the company should implement procedures and practices for collection, interpretation and processing of product, process- and service-related data (Ulaga and Reinartz, 2011). Similarly, traditional information technologies should be integrated with new ones (such as internet-of-things), enabling data collection, interpretation and reporting (Neff et al., 2014). Consequently, companies need to acquire or develop the capability to collect product-, process-, service-related data and interpret them, and in particular, to analyze data collected from the installed base (Ulaga and Reinartz, 2011).

As the availability of financial resources is a prerequisite for servitized BM (Tukker, 2004), a company needs to elaborate business plans to acquire financial resources (Azarenko et al., 2009; Ng et al., 2013) and, at the same time, procedures to manage financial resources allocation (Mont, 2006; Barquet et al., 2013).

4.2.6 Partnerships. Companies may decide to outsource activities or acquire external resources to deliver services (Gebauer et al., 2013). Selecting partners is, therefore, essential to develop a network that delivers services effectively, as it is consequently the capability to measure their performances over time (Kindström, 2010; Storbacka, 2011; Kindström and Kowalkowski, 2014). As in a servitized environment, relationships with partners are crucial, (Saccani et al., 2014) procedures and practices for drawing-up agreements with key partner/ suppliers are needed to formalize and specify contractually the responsibilities and obligations of all parties ( $\mathrm{Ng}$ et al., 2013). Another crucial aspect is the sharing of data with partners, to build trust and strengthen relationships (Gebauer et al., 2013), relying on information systems and tools for information sharing with the network (Storbacka, 2011; Kindström and Kowalkowski, 2014). 
4.2.7 Channels. Companies need to rethink how they create customer awareness (Kindström et al.,2015) and deliver offerings. A company should establish sales teams/key account managers to interact with key customers and create a "service-savvy" sales force (Ulaga and Loveland, 2014). This may lead to the reconfiguration of the sales channel through internalization or externalization (Kindström et al., 2015).

A similar development path has to be followed for after-sales service channels, where the establishment of a field service network allows venturing into more complex offerings (Ulaga and Reinartz, 2011). In fact, in addition to selling and delivering services, the after-sales channel collects critical information about customers, service operations and the market (Gebauer and Kowalkowski, 2012).

4.2.8 Cost structure. Companies need to assess the cost of servitized offerings (Datta and Roy, 2010). To this end, specific metrics have to be defined (e.g. to evaluate service-related activities costs, financial performances, fleet financial costs, etc.) using, for example, data collected from the installed base (Storbacka, 2011; Barquet et al., 2013). Moreover, traditional cost assessment procedures are no longer suitable in the new setting, and tools for reporting and cost accounting of product-service solutions are required (Datta and Roy, 2010). The evaluation of how risks are shared among the company, its suppliers/partners and the customer is critical in servitized BMs. To this end, companies should develop the capabilities to evaluate operating and financial risks and manage uncertainty, to distribute risks to other network partners and to design and implement safeguarding mechanisms (Nordin et al., 2011; Kindström and Kowalkowski, 2014). Moreover, procedures have to be implemented to formalize and manage financial and operating risks (Tukker, 2004; Nordin et al., 2011). Finally, mechanisms to reduce customers' liability risks and enhance control over production uncertainties should be arranged (Azarenko et al., 2009).

4.2.9 Revenue model. Several revenue generation mechanisms can be developed in servitized BMs, which require new pricing capabilities (Bonnemeier et al., 2010; Rapaccini, 2015). As payments may be based on the availability of the product and/or service, on the usage intensity, or on the results achieved (Barquet et al., 2013), the capability to define reliable outcome expectations with the customer and define the corresponding metrics/parameters to evaluate the agreed outcome are required (Meier et al., 2010; Storbacka, 2011; Ulaga and Reinartz, 2011).

\subsection{SeMM operationalization}

In the MM literature, a common design principle is to represent maturity as a number of cumulative stages (generally five) with a logical progression (de Bruin et al., 2005). The SeMM, thus, operationalizes the maturity concept with five-stage scales to measure the service orientation of each requirement (Table III). We mostly adopt standard scales based on the literature (one for each dimension), but also develop ad hoc ones when needed to take into account the peculiarities of some requirement.

Based on the evidence collected at the companies, we assign a maturity score to each requirement, ranging from 1 (no service orientation) to 5 (highest servitization maturity). By aggregating the scores of the requirements according to the BM component and/or maturity dimension they belong, the SeMM provides a maturity level for each dimension and for each $\mathrm{BM}$ component. By averaging out such scores, an average servitization maturity score for the company is obtained. Figure 2 provides examples of radar charts visualizing the maturity of $\mathrm{BM}$ components and maturity dimensions and of their disaggregation into the constituting requirements.

\section{Empirical application}

The SeMM has been applied to two companies undertaking a servitization journey, HSM and FORK. HSM is a medium Italian company that manufactures high-speed milling systems, 
$\underset{31,4}{\text { JMTM }}$

786

(1)

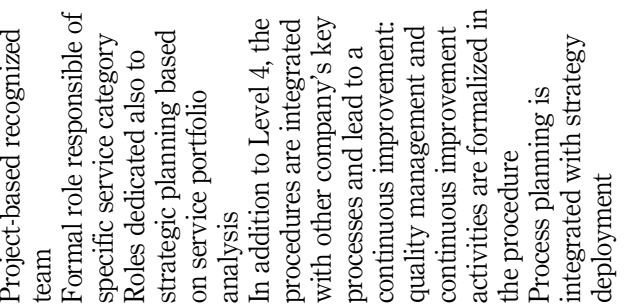

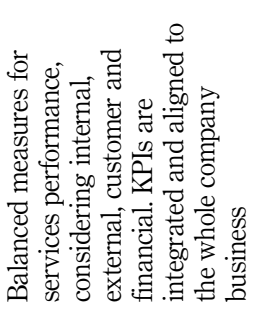

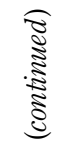

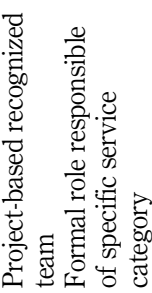

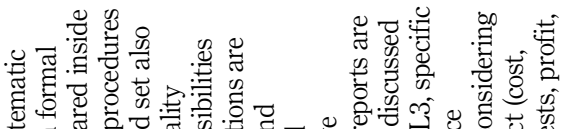

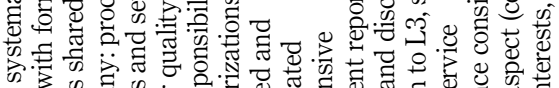
क.

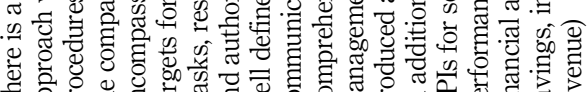

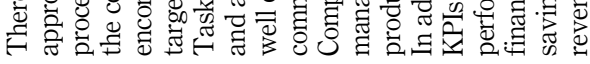

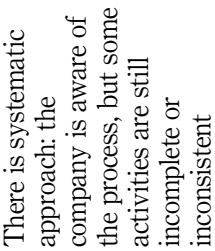

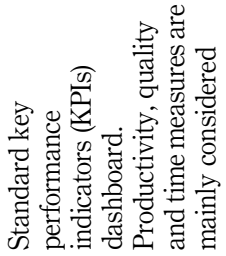

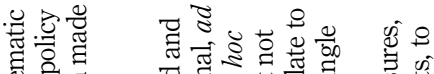

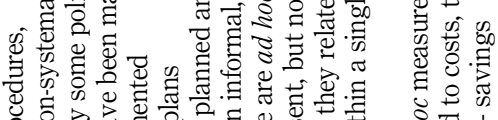

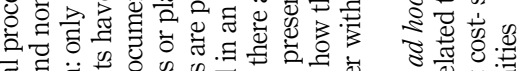

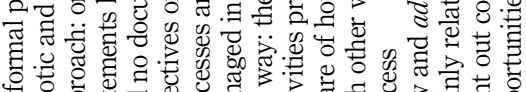

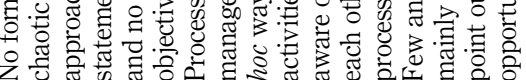

Table III.

Standard scales adopted in the SeMM

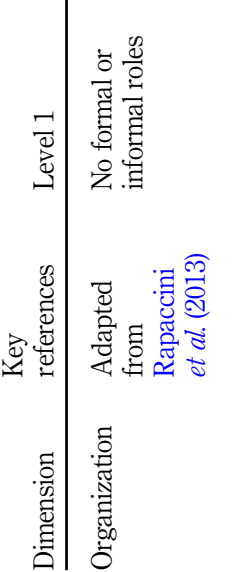

0

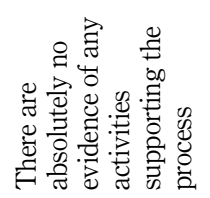

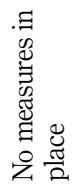

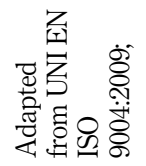

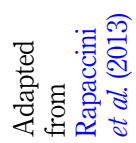

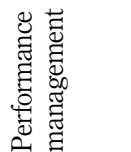




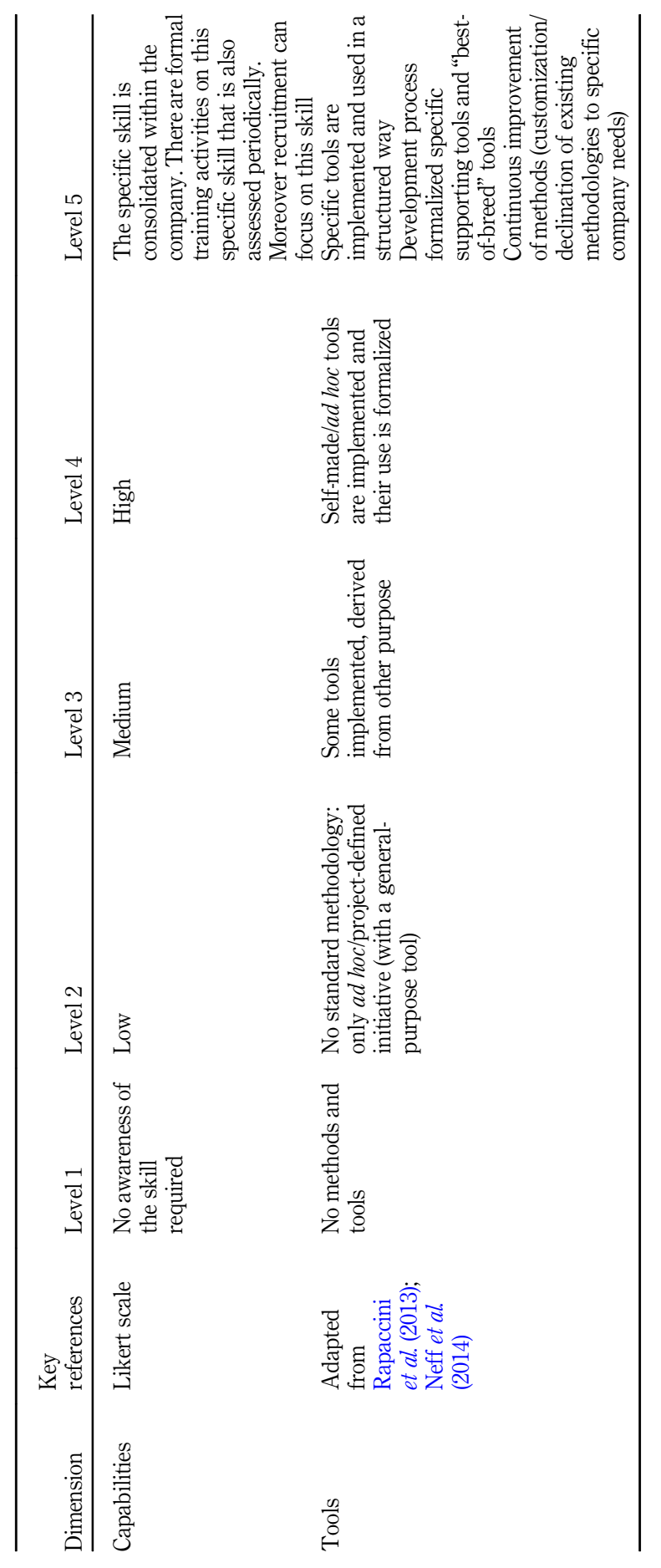

Servitization

787

Table III. 
JMTM 31,4

\section{8}

Figure 2.

SeMM structure
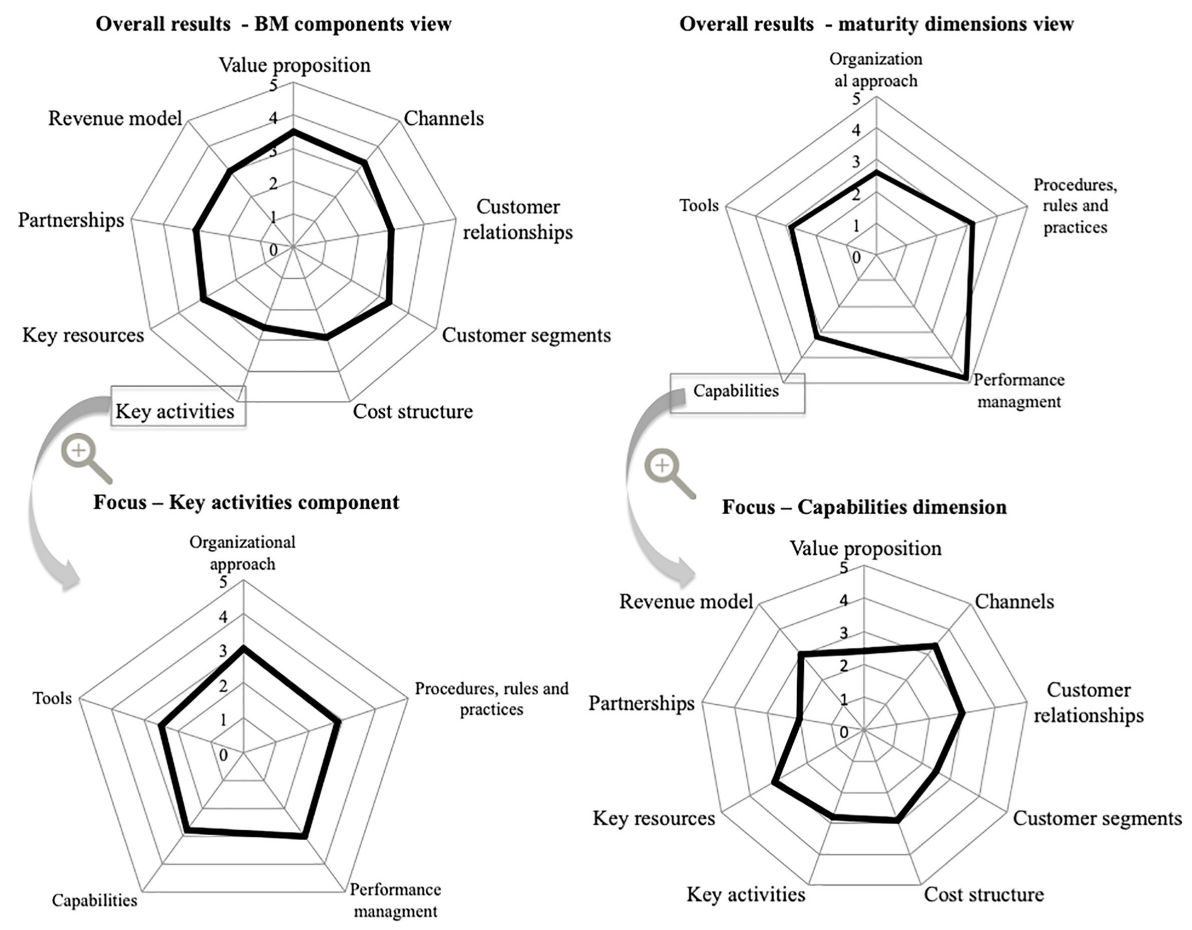

characterized by a high customization and flexibility. Machine sales represent the greatest part of the turnover (more than 75 percent), while after-sales services were traditionally considered a "necessary evil," and only recently, the company has started focusing on the development of the service business. The service portfolio is still mainly made of base services, such as technical assistance, training and spare parts provision. FORK is a medium Spanish firm operating in the forklift truck sector. Its business evolved in the past ten years from a reseller to being mainly a forklift rental company. Today, FORK has a fleet of over 2,000 forklift trucks on long-term rental and a related business of financial and after-sales services.

\subsection{Servitization maturity assessment}

The assessment of the servitization maturity leads to two very different pictures. Figure 3 shows that, both in the maturity dimensions and BM components, FORK is consistently positioned slightly below or above Level 4, while HSM generally stands around Level 2[1]. In the following, the results of the SeMM application are briefly presented, grouped by key components.

Key activities - HSM has no explicit strategy for both existing and new services. FORK, instead, has structured processes and responsibilities for the development of new services, adopts service engineering methods and specific workflows to guide the service design phase, ensuring the participation of different business functions. On the contrary, HSM has no procedures and practices for managing the integration between product and service development. Similarly, while FORK adopts clearly defined procedures for service delivery (e.g. technical support, help desk, etc.), in HSM, these are still missing. In addition, FORK has a service business unit with profit and loss responsibility. 

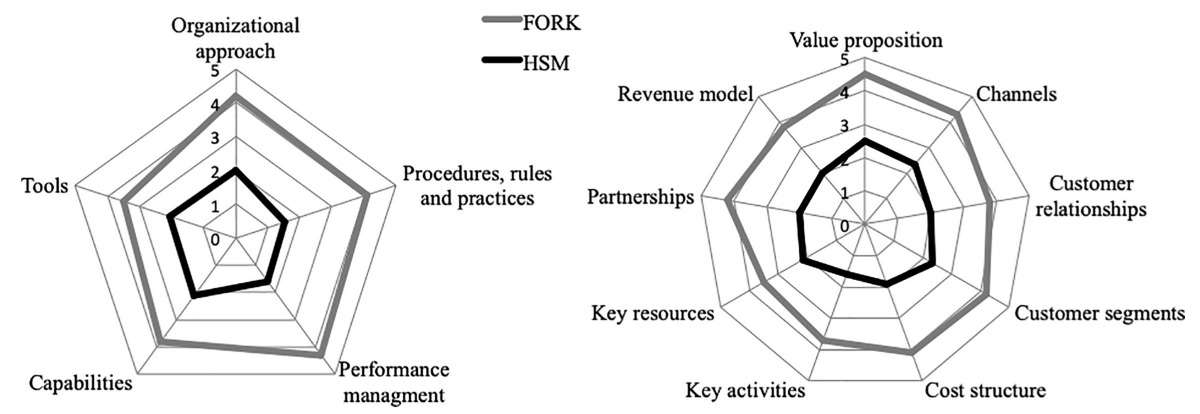

Servitization

Revenue and costs - HSM has no specific metrics to measure service-related operational performances (e.g. response time, quality, etc.) and costs, and the management acknowledges that this may be critical when new services related to a newly developed remote monitoring system will be launched. FORK, on the other hand, has detailed indicators to monitor services performance, encompassing internal, external, customer and financial aspects. Moreover, FORK has also developed the capability to design safeguarding mechanisms and to evaluate operational and financial risks. As the latter aspect is critical also to determine how to price services, FORK is able to charge its rental fleet with periodic fees that also include periodic maintenance. On the opposite, HSM adopts a traditional one-off transactional revenue model.

Key resources - In HSM, the technical know-how (mechanical and software) represents the core competence. However, the low level of service orientation in the organization could hinder the development of servitized offerings requiring to move some key employees from purely technical roles to service-related ones. On the other hand, FORK has moved from emphasizing only technical product features to a service delivery logic, and specific roles are set in the organizational chart to promote services and to be a unique touch point for the customer. Both companies are rather immature in terms of ICT tools and monitoring technologies: a common critical aspect is the data collection from the installed base. However, they have recently implemented sensors and tools for data collection and product health management, which will enable the collection and elaboration of data about equipment and customer operations, allowing to strengthen customer relationships.

Channels and partnerships - Besides the common involvement of partners in the technological development of remote monitoring systems, great differences emerge. In fact, while FORK has designed a field service network made both by internal personnel and external service partners, HSM has not yet structured its channels to provide field services effectively. FORK, moreover, has a formalized set of criteria for partner selection and has improved the communication and information sharing with its sales and service network to secure transparency and visibility.

Customer segmentations and relationships - While FORK adopts ad hoc tools to ease the information exchange with customers, HSM instead still collects few data from customers, using spreadsheets not integrated with the enterprise resource system (ERP) system (e.g. technical and fault reports). Consequently, no formal procedures for managing customer feedbacks are present in HSM, while FORK has implemented workflows to collect and manage feedbacks on product/service experience. This also allows FORK to better understand customer preferences and needs: thanks to the data collected, FORK has developed customer segmentation criteria. HSM, instead currently lacks the capability to design customer-specific value propositions. 
JMTM 31,4

790

\subsection{SeMM usage and improvement actions}

HSM has recently introduced a new smart spindle in the machines and aims to develop preventive and predictive maintenance services, thanks to this technological innovation and to a condition-based monitoring tool (designed by a partner). Instead, FORK aims to develop a new short-term rental business (i.e. rentals ranging from few days to two months), to increasingly exploit its fleet. This offering will include a novel full-service contract to customers and a daily rental fee based on the actual forklift usage (pay-x-use). The short-term rental will rely on a novel field management system that allows FORK to monitor and analyze the signals collected from the forklift (e.g. working hours, battery level, engine temperature, etc.).

Based on the maturity assessment previously illustrated and the innovations and objectives described above, FORK and HSM identified a set of actions to improve their servitization maturity and sustain the development of the new offering. The actions are listed in Table IV.

\section{Conclusion}

\subsection{Theoretical contribution}

A need for studies aimed at describing and prescribing how to servitize a product-centric firm has been observed (Baines et al., 2017). The MM developed in this paper contributes to fill this gap and to accumulate knowledge on the service transformation of product-centric companies. The model has an original bi-dimensional structure, combining five maturity dimensions with the BM Canvas components. Through the identification of 85 detailed critical requirements, it provides a comprehensive understanding of the service transition phenomenon. In particular, it helps addressing some among the most acknowledged challenges of servitization, the cultural readiness and the top management commitment (Oliva and Kallenberg, 2003; Gebauer et al., 2005, Martinez et al., 2010). In fact, the SeMM generates awareness about the critical aspects to be controlled, contributing to the creation of a company culture about the many elements, both inward and customer-facing, to be considered and aligned when undertaking a servitization journey. In addition, as several challenges hinder the achievement of the expected strategic, financial and marketing benefits of servitization (Zhang and Banerji, 2017), the choice of using BM components as one of the axis of our SeMM helps reading servitization in the light of the BM transformations needed, on each component and at each maturity stage. The identification of gaps in single requirements or in their aggregation (e.g. BM components) supports the definition and prioritization of the actions and transformations required to servitize, as shown by the case studies.

Another specific contribution of this paper stands in the operationalization of the servitization concept, thanks to the definition of critical requirements and their measurement scales, that address another research gap observed in the literature. In fact, it has been pointed out that servitization measures are varied and inconsistent across studies (Calabrese et al., 2019) and mostly based on one single indicator, such as the number of services (or service types) offered or the share of revenue made from services. Servitization being a largely intra- and inter-organizational multidisciplinary matter, linking its measure simply to an output indicator cannot capture the complexity of the phenomenon (Lütjen et al., 2017). The adoption of a multidimensional and comprehensive perspective on the organization and its relationships, instead, appears as more appropriate way to deal with the measure of servitization.

Finally, because SMEs often do not possess the resources or the experience to successfully servitize (Kowalkowski et al., 2013), this research contributes to the development of guidelines and tools that SMEs can apply for pointing out the capabilities, resources and organizational changes needed that are advocated in the literature (Adrodegari et al., 2017; Baines et al., 


\begin{tabular}{ll}
\hline BM component & HSM \\
\hline Value & (1) Develop a new service culture and \\
proposition & $\begin{array}{l}\text { attitude } \\
\text { (2) Include the new predictive maintenance } \\
\text { service in the traditional portfolio } \\
\text { (3) Design the new offerings: software and }\end{array}$ \\
& related services \\
(1) Implementation of specific ICT tools to \\
relationships & $\begin{array}{l}\text { ease the relationships with customers (e.g. } \\
\text { customer relationship management (CRM), } \\
\text { trouble ticketing, etc.) } \\
\text { (2) Formalize specific procedures to manage } \\
\text { customer feedbacks } \\
\text { (3) Develop relational capabilities both in the } \\
\text { sales and after-sales personnel } \\
\text { (1) Design a periodic survey to assess } \\
\text { customer }\end{array}$ \\
$\begin{array}{l}\text { (2) Develop new customer segmentation } \\
\text { criteria and accordingly manage the }\end{array}$ \\
customer portfolio \\
(3) Develop the capability to customize value \\
proposition to meet actual customer needs
\end{tabular}

Key activities (1) Establishment of service business unit

(2) Formalization of workflow for the service design phase

(3) Formalization of workflow for the service planning and delivery phase

(4) Implementation of tools for managing service-related activities and enable predictive maintenance

(5) Identification of relevant KPIs, especially related to the service function

(6) Design specific marketing initiative for new full-service contracts

(7) Define procedure that formalize and standardize the data collection, interpretation and processing (from product and service activities)

Key resources (1) Define new service roles in the organization chart

(2) Define new job profiles to acquire specific capabilities needed

(3) Develop a project management and planning attitude

(4) Integration/migration of the data manually collected into the ERP

(5) Exploit the functionalities of the new condition-based monitoring tool

(6) Use new techniques for product design accordingly to the service requirements (e.g. implementation of new diagnostic sensor on the machines; adoption of design-for-X techniques)
FORK

Servitization

(1) Design the lifecycle cost models of the new short-term rental model

(2) Define the value of the new offering compared to long-term rental

(1) Implement a Web portal for short-term rental customers: ticketing, renting and automatic configuration of the forklift (2) Improve the existing internal procedure for managing customer feedback to use these feedbacks for product/service improvement and strengthen customer relationships

(1) Adapt the existing customer advisory procedure to better define the new shortterm rental value to each customer segment

(1) Create a dedicated team for the analysis and interpretation of new signals collected from the forklift

(2) Improve the current procedure for forklifts refurbishment (i.e. initial diagnosis, disassembly, painting and repair, assembly and final quality tests) (3) Improve logistics and reverse logistics processes

(4) Develop specific marketing initiative to promote the short-term rental model aiming to clarify the new values for the customers

(1) Exploit the functionalities of the new fleet management and health management systems

(2) Implement additional devices for the connectivity of the forklift

(3) Implement new additional sensors on the battery (i.e. monitoring the electric energy consumption will help to understand the real usage of the battery and when it needs to be regenerated)

(4) Implement geo-localization of the forklift to ease their quick (re)-allocation in the short-term rental business 
Partnerships (1) Develop new external partnerships to provide maintenance in countries where HSM is not present with a direct subsidiary (2) Define procedures that help to formalize and specify contractually the responsibilities and obligations of all parties (1) Design a new after-sales channel, structuring a field service network (2) Define a new unique touching point (e.g. "sales support and customer service profile") (3) Periodic inter-firms meeting to ease the interaction among sales and after-sales channels

Cost structure

(1) Formalize procedures for financial risk assessment and evaluation

(2) Formalize procedures for operational risk assessment and evaluation

Revenue model

(1) Develop new pricing capabilities

(2) Definition of new reliable outcome expectations with the customer for the new predictive service

(3) Formalize the reward system and explicitly indicate that it is oriented to something different than new product sale
(1) Develop new partnerships with local logistics providers and financial service providers

(2) Design specific indicators to monitor partners' performances in the short-term rental business

(1) Manage the coexistence of short- and long-term rental models

(1) Develop a total cost of ownership tool for the short-term rental

(2) Adapt the existing procedure for financial risk assessment to short-term rental

(1) Align incentive and rewards systems to new strategic short-term rental objectives (2) Develop a new capability to elaborate business plans to quantify to customers the new value of the short-term rental business

Table IV.

2017). For instance, a critical aspect for SMEs concerns the sales and service channels, which are often intermediated (Gebauer et al., 2010): consequently, partnerships have a key role in providing SMEs access to the end-customer base and/or the additional capabilities needed to develop and sell service offerings (Kowalkowski et al., 2013; Paiola et al., 2013). Those aspects are explicitly assessed in the SeMM, showing how the critical requirements structure proposed can guide SMEs in identifying the key aspects for their servitization journey and the improvement actions to be undertaken.

\subsection{Managerial implications}

From a managerial perspective, the SeMM responds to the call for application-oriented research (Baines et al., 2017). The model provides a way to assess the servitization maturity of the five dimensions and nine BM components, also in a visual fashion (Figures 2 and 3), suggesting priority action areas for the company management. Therefore, managers can use the proposed model to identify and bridge the (internal and external) gaps to successfully deploy the new BM, selecting specific actions to overcome them, as it has been shown through the case application in section 5.

In particular, the model can be particularly useful to SMEs, supporting practitioners in the servitization journey through a rigorous yet practical tool, helping them bridging the distance with large companies. In fact, the SeMM supports managers, to successfully leverage, coordinate and align the transformations needed to servitize.

Moreover, the cases show how the model can be applied in product-centric companies coming from both a pure manufacturing background - having traditionally conceived services as a "necessary evil" - and from a reseller/distributor one - seeking to create value for the customer through additional services and new revenue models. 


\subsection{Limitations and research opportunities}

This study comes with some limitations, suggesting avenues for future research. First, the empirical application relies on two case studies only, and it should be extended to additional companies and sectors to verify its reliability and consistency.

Second, although the SeMM lists 85 critical requirements, some crossings between BM components and maturity dimensions are not described by any item. Future research could focus on these crossings, to identify critical requirements to be added to the current set.

Third, further studies may investigate the relationships among the critical requirements identified, leading to the definition of archetypal configurations of servitized BMs (i.e. configurations of the requirements for specific value propositions, such as "pay-per-use").

Finally, as companies may adopt different BMs simultaneously (e.g. to address different markets or customer segments), future research may investigate how the SeMM can support companies in defining the configuration of resources and capabilities in a multiple BM perspective.

\section{Note}

1. A detailed evaluation of the requirements for each company can be provided upon request.

\section{References}

Adrodegari, F. and Saccani, N. (2017), "Business models for the service transformation of industrial firms", Service Industries Journal, Vol. 37 No. 1, pp. 57-83.

Adrodegari, F., Saccani, N., Kowalkowski, C. and Vilo, J. (2017), "PSS business model conceptualization and application", Production Planning and Control, Vol. 28 No. 15, pp. 1251-1263.

Adrodegari, F., Bacchetti, A., Saccani, N., Arnaiz, A. and Meiren, T. (2018), "The transition towards service-oriented business models: a European survey on capital goods manufacturers", International Journal of Engineering Business Management, Vol. 10, 1847979018754469.

Alghisi, A. and Saccani, N. (2015), "Internal and external alignment in the servitization journeyovercoming the challenges", Production Planning and Control, Vol. 26 Nos 14-15, pp. 1219-1232.

Ayala, N.F., Paslauski, C.A., Ghezzi, A. and Frank, A.G. (2017), "Knowledge sharing dynamics in service suppliers' involvement for servitization of manufacturing companies", International Journal of Production Economics, Vol. 193, pp. 538-553.

Alvarez, R.L., Martins, M.R. and Silva, M.T. (2015), "Applying the maturity model concept to the servitization process of consumer durables companies in Brazil", Journal of Manufacturing Technology Management, Vol. 26 No. 8, pp. 1086-1106.

Ardolino, M., Rapaccini, M., Saccani, N., Gaiardelli, P., Crespi, G. and Ruggeri, C. (2018), "The role of digital technologies for the service transformation of industrial companies", International Journal of Production Research, Vol. 56 No. 6, pp. 2116-2132.

Azarenko, A., Roy, R., Shehab, E. and Tiwari, A. (2009), "Technical product-service systems: some implications for the machine tool industry", Journal of Manufacturing Technology Management, Vol. 20 No. 5, pp. 700-722.

Baines, T.S., Lightfoot, H.W., Benedettini, O. and Kay, J.M. (2009), “The servitization of manufacturing: a review of literature and reflection on future challenges", Journal of Manufacturing Technology Management, Vol. 20 No. 5, pp. 547-567.

Baines, T. and Lightfoot, H. (2013), Made to serve. How manufacturers can compete through servitization and product-service systems, Wiley publications.

Baines, T., Ziaee Bigdeli, A., Bustinza, O.F., Shi, V.G., Baldwin, J. and Ridgway, K. (2017), "Servitization: revisiting the state-of-the-art and research priorities", International Journal of Operations and Production Management, Vol. 37 No. 2, pp. 256-278. 
JMTM 31,4
Barquet, A.P.B., de Oliveira, M.G., Amigo, C.R., Cunha, V.P. and Rozenfeld, H. (2013), "Employing the business model concept to support the adoption of product-service systems (PSS)", Industrial Marketing Management, Vol. 42 No. 5, pp. 693-704.

Benedettini, O., Neely, A. and Swink, M. (2015), "Why do servitized firms fail? A risk-based explanation", International Journal of Operations and Production Management, Vol. 35 No. 6, pp. 946-979.

Berg, P., Leinonen, M., Leivo, V. and Pihlajamaa, J. (2002), "Assessment of quality and maturity level of RandD”, International Journal of Production Economics, Vol. 78, pp. 29-35.

Bonnemeier, S., Burianek, F. and Reichwald, R. (2010), "Revenue models for integrated customer solutions: concept and organizational implementation", Journal of Revenue and Pricing Management, Vol. 9 No. 3, pp. 228-238.

Brax, S.A. and Visintin, F. (2017), "Meta-model of servitization: the integrative profiling approach", Industrial Marketing Management, Vol. 60, pp. 17-32.

Calabrese, A., Levialdi Ghiron, N., Tiburzi, L., Baines, T. and Ziaee Bigdeli, A. (2019), "The measurement of degree of servitization: literature review and recommendations", Production Planning and Control, Vol. 30 No. 13, pp. 1118-1135.

Clegg, B., Little, P., Govette, S. and Logue, J. (2017), "Transformation of a small-to-medium-sized enterprise to a multi-organisation product-service solution provider", International Journal of Production Economics, Vol. 192, pp. 81-91.

Cooke-Davies, T.J. and Arzymano, A. (2003), "The maturity of project management in different industries: an investigation into variations between project management models", International Journal of Project Management, Vol. 21, pp. 471-478.

Coreynen, W., Matthyssens, P. and Van Bockhaven, W. (2017), "Boosting servitization through digitization: pathways and dynamic resource configurations for manufacturers", Industrial Marketing Management, Vol. 60, pp. 42-53.

Correia, E., Carvalho, H., Azevedo, S. and Govindan, K. (2017), "Maturity models in supply chain sustainability: a systematic literature review", Sustainability, Vol. 9 No. 1p. 64.

Datta, P.P. and Roy, R. (2010), "Cost modelling techniques for availability type service support contracts: a literature review and empirical study", CIRP Journal of Manufacturing Science and Technology, Vol. 3 No. 2, pp. 142-157.

Davies, A., Brady, T. and Hobday, M. (2007), "Organizing for solutions: systems seller vs. systems integrator”, Industrial Marketing Management, Vol. 36 No. 2, pp. 183-193.

de Bruin, T., Rosemann, M., Freeze, R. and Kulkarni, U. (2005), "Understanding the main phases of developing a maturity assessment model", Proceedings of ACIS, Sydney.

de Jesus Pacheco, D.A., ten Caten, C.S., Jung, C.F., Sassanelli, C. and Terzi, S. (2019), "Overcoming barriers towards sustainable product-service systems in small and medium-sized enterprises: state of the art and a novel decision matrix", Journal of Cleaner Production, Vol. 222, pp. 903-921.

Forkmann, S., Ramos, C., Henneberg, S.C. and Naudé, P. (2017), "Understanding the service infusion process as a business model reconfiguration”, Industrial Marketing Management, Vol. 60, pp. 151-166.

Fraser, P., Moultrie, J. and Gregory, M. (2002), “The use of maturity models/grids as a tool in assessing product development capability", IEEE international engineering management conference, IEEE, Vol. 1, pp. 244-249.

Gebauer, H., Fleisch, E. and Friedli, T. (2005), "Overcoming the service paradox in manufacturing companies”, European Management Journal, Vol. 23 No. 1, pp. 14-26.

Gebauer, H., Paiola, M. and Edvardsson, B. (2010), "Service business development in small and medium capital goods manufacturing companies", Managing Service Quality: International Journal, Vol. 20 No. 2, pp. 123-139. 
Gebauer, H. and Kowalkowski, C. (2012), "Customer-focused and service-focused orientation in organizational structures", Journal of Business and Industrial Marketing, Vol. 27 No. 7, pp. 527-537.

Gebauer, H., Paiola, M. and Saccani, N. (2013), "Characterizing service networks for moving from products to solutions", Industrial Marketing Management, Vol. 42 No. 1, pp. 31-46.

Jin, D., Chai, K.H. and Tan, K.C. (2014), "New service development maturity model”, Managing Service Quality: International Journal, Vol. 24 No. 1, pp. 86-116.

Keränen, J. and Jalkala, A. (2013), "Towards a framework of customer value assessment in B2B markets: an exploratory study”, Industrial Marketing Management, Vol. 42 No. 8, pp. 1307-1317.

Kindström, D. and Kowalkowski, C. (2009), "Development of industrial service offerings: a process framework", Journal of service Management, Vol. 20 No. 2, pp. 156-172.

Kindström, D. and Kowalkowski, C. (2014), "Service innovation in product-centric firms: a multidimensional business model perspective", Journal of Business and Industrial Marketing, Vol. 29 No. 2, pp. 96-111.

Kindström, D. (2010), "Towards a service-based business model - key aspects for future competitive advantage", European Management Journal, Vol. 28 No. 6, pp. 479-490.

Kindström, D., Kowalkowski, C. and Alejandro, T.B. (2015), "Adding services to product-based portfolios: an exploration of the implications for the sales function", Journal of Service Management, Vol. 26 No. 3, pp. 372-393.

Kowalkowski, C. (2011), "Dynamics of value propositions: insights from service-dominant logic", European Journal of Marketing, Vol. 45 Nos 1/2, pp. 277-294.

Kowalkowski, C., Witell, L. and Gustafsson, A. (2013), "Any way goes: identifying value constellations for service infusion in SMEs", Industrial Marketing Management, Vol. 42 No. 1, pp. 18-30.

Kowalkowski, C., Gebauer, H., Kamp, B. and Parry, G. (2017), "Servitization and deservitization: overview, concepts, and definitions", Industrial Marketing Management, Vol. 60, pp. 4-10.

Li, H., Ji, Y., Gu, X., Bao, Z. and Qi, G. (2014), “A universal enterprise manufacturing services maturity model: a case study in a Chinese company", International Journal of Computer Integrated Manufacturing, Vol. 27 No. 5, pp. 434-449.

Lockamy, A. III and McCormack, K. (2004), "The development of a supply chain management process maturity model using the concepts of business process orientation", Supply Chain Management: International Journal, Vol. 9 No. 4, pp. 272-278.

Lütjen, H., Tietze, F. and Schultz, C. (2017), "Service transitions of product-centric firms: an explorative study of service transition stages and barriers in Germany's energy market", International Journal of Production Economics, Vol. 192, pp. 106-119.

Machado, C.G., de Lima, E.P., da Costa, S.E.G., Angelis, J.J. and Mattioda, R.A. (2017), "Framing maturity based on sustainable operations management principles", International Journal of Production Economics, Vol. 190, pp. 3-21.

Martinez, V., Bastl, M., Kingston, J. and Evans, S. (2010), "Challenges in transforming manufacturing organisations into product-service providers", Journal of Manufacturing Technology Management, Vol. 21 No. 4, pp. 449-469.

Martinez Hernandez, V., Neely, A., Velu, C., Leinster-Evans, S. and Bisessar, D. (2017), "Exploring the journey to services", International Journal of Production Economics, Vol. 192, pp. 66-80.

Meier, H., Roy, R. and Seliger, G. (2010), "Industrial product-service systems-IPS2", CIRP Annals Manufacturing Technology, Vol. 59 No. 2, pp. 607-627.

Mittal, S., Khan, M.A., Romero, D. and Wuest, T. (2018), "A critical review of smart manufacturing and Industry 4.0 maturity models: implications for small and medium-sized enterprises (SMEs)", Journal of Manufacturing Systems, Vol. 49, pp. 194-214.

Mont, O., Dalhammar, C. and Jacobsson, N. (2006), "A new business model for baby prams based on leasing and product remanufacturing", Journal of Cleaner Production, Vol. 14 No. 17, pp. 1509-1518. 
JMTM 31,4

Neely, A. (2008), "Exploring the financial consequences of the servitization of manufacturing", Operations Management Research, Vol. 1 No. 2, pp. 103-118.

Neff, A.A., Hamel, F., Herz, T.P., Uebernickel, F., Brenner, W. and vom Brocke, J. (2014), "Developing a maturity model for service systems in heavy equipment manufacturing enterprises", Information and management, Vol. 51 No. 7, pp. 895-911.

Ng, I.C., Ding, D.X. and Yip, N. (2013), "Outcome-based contracts as new business model: the role of partnership and value-driven relational assets”, Industrial Marketing Management, Vol. 42 No. 5, pp. 730-774.

Niemi, P., Huiskonen, J. and Kärkkäinen, H. (2009), "Understanding the knowledge accumulation process - implications for the adoption of inventory management techniques", International Journal of Production Economics, Vol. 118 No. 1, pp. 160-167.

Nordin, F. and Kowalkowski, C. (2010), "Solutions offerings: a critical review and reconceptualisation", Journal of Service Management, Vol. 21 No. 4, pp. 441-459.

Nordin, F., Kindström, D., Kowalkowski, C. and Rehme, J. (2011), "The risks of providing services: differential risk effects of the service-development strategies of customisation, bundling, and range", Journal of Service Management, Vol. 22 No. 3, pp. 390-408.

Oliva, R. and Kallenberg, R. (2003), "Managing the transition from products to services", International Journal of Service Industry Management, Vol. 14 No. 2, pp. 160-172.

Osterwalder, A. and Pigneur, Y. (2010), Business Model Generation: A Handbook for Visionaries, Game Changers, and Challengers, John Wiley \& Sons, Hoboken, New Jersey.

Paiola, M., Saccani, N., Perona, M. and Gebauer, H. (2013), "Moving from products to solutions: strategic approaches for developing capabilities”, European Management Journal, Vol. 31 No. 4, pp. 390-409.

Paulk, M.C., Curtis, B., Chrissis, M.B. and Weber, C.V. (1993), The Capability Maturity Model for Software, Version 1.1, (No. CMU/SEI-93-TR-24), Software Engineering Institute, Pittsburgh, PA.

Pigosso, D.C. and McAloone, T.C. (2016), "Maturity-based approach for the development of environmentally sustainable product/service-systems. CIRP”, Journal of Manufacturing Science and Technology, Vol. 15, pp. 33-41.

Pöppelbuß, J. and Röglinger, M. (2011), "What makes a useful maturity model? A framework of general design principles for maturity models and its demonstration in business process management", ECIS Proceedings, AIS Electronic Library, pp. 28, available at: https://aisel.aisnet. org/ecis2011/28.

Rapaccini, M., Saccani, N., Pezzotta, G., Burger, T. and Ganz, W. (2013), "Service development in product-service systems: a maturity model", Service Industries Journal, Vol. 33 Nos 3-4, pp. 300-319.

Raddats, C., Kowalkowski, C., Benedettini, O., Burton, J. and Gebauer, H. (2019), "Servitization: a contemporary thematic review of four major research streams", Industrial Marketing Management, Vol. 83, November 2019, pp. 207-223, doi: 10.1016/j.indmarman.2019.03.015.

Rapaccini, M. (2015), "Pricing strategies of service offerings in manufacturing companies: a literature review and empirical investigation", Production Planning and Control, Vol. 26 Nos 14-15, pp. $1247-1263$.

Reim, W., Parida, V. and Örtqvist, D. (2015), "Product-Service Systems business models and tactics-a systematic literature review", Journal of Cleaner Production, Vol. 97, pp. 61-75.

Röglinger, M., Pöppelbuß, J. and Becker, J. (2012), "Maturity models in business process management", Business Process Management Journal, Vol. 18 No. 2, pp. 328-346 doi: 10.1108/ 14637151211225225.

Saccani, N., Visintin, F. and Rapaccini, M. (2014), "Investigating the linkages between service types and supplier relationships in servitized environments", International Journal of Production Economics, Vol. 149, pp. 226-238. 
Saul, C.J. and Gebauer, H. (2018), "Born solution providers-Dynamic capabilities for providing solutions", Industrial Marketing Management, Vol. 73, pp. 31-46.

Storbacka, K. (2011), "A solution business model: capabilities and management practices for integrated solutions”, Industrial Marketing Management, Vol. 40 No. 5, pp. 699-711.

Storbacka, K., Windahl, C., Nenonen, S. and Salonen, A. (2013), "Solution business models: transformation along four continua”, Industrial Marketing Management, Vol. 42 No. 5, pp. 705-716.

Suppatvech, C., Godsell, J. and Day, S. (2019), "The roles of internet of things technology in enabling servitized business models: a systematic literature review", Industrial Marketing Management, Vol. 82, October 2019, pp. 70-86, doi: 10.1016/j.indmarman.2019.02.016.

Tarhan, A., Turetken, O. and Reijers, H.A. (2016), "Business process maturity models: a systematic literature review", Information and Software Technology, Vol. 75, pp. 122-134.

Teece, D.J. (2010), "Business models, business strategy and innovation”, Long Range Planning, Vol. 43 Nos 2-3, pp. 172-194.

Tukker, A. (2004), "Eight types of product-service system: eight ways to sustainability? Experiences from SusProNet", Business Strategy and the Environment, Vol. 13 No. 4, pp. 246-260.

Tukker, A. (2015), "Product services for a resource-efficient and circular economy-a review", Journal of Cleaner Production, Vol. 97, pp. 76-91.

Ulaga, W. and Loveland, J.M. (2014), "Transitioning from product to service-led growth in manufacturing firms: emergent challenges in selecting and managing the industrial", Industrial Marketing Management, Vol. 43 No. 1, pp. 113-125.

Ulaga, W. and Reinartz, W.J. (2011), "Hybrid offerings: how manufacturing firms combine goods and services successfully", Journal of Marketing, Vol. 75 No. 6, pp. 5-23.

Van Looy, A. (2014), Business Process Maturity: A Comparative Study on a Sample of Business Process Maturity Models, Springer Science and Business Media, Spinger, doi: 10.1007/978-3-319-04202-2.

Valtakoski, A. and Witell, L. (2018), "Service capabilities and servitized SME performance: contingency on firm age", International Journal of Operations and Production Management, Vol. 38 No. 4, pp. 1144-1164.

Voss, C., Tsikriktsis, N. and Frohlich, M. (2002), "Case research in operations management", International Journal of Operations and Production Management, Vol. 22 No. 2, pp. 195-219.

Wendler, R. (2012), "The maturity of maturity model research: a systematic mapping study", Information and Software Technology, Vol. 54 No. 12, pp. 1317-1339.

Wikström, K., Hellström, M., Artto, K., Kujala, J. and Kujala, S. (2009), "Services in project-based firms-Four types of business logic", International Journal of Project Management, Vol. 27 No. 2, pp. 113-122.

Yoo, C., Yoon, J., Lee, B., Lee, C., Lee, J., Hyun, S. and Wu, C. (2006), "A unified model for the implementation of both ISO 9001:2000 and CMMI by ISO-certified organizations", Journal of Systems and Software, Vol. 79, pp. 954-961.

Zhang, W. and Banerji, S. (2017), "Challenges of servitization: a systematic literature review", Industrial Marketing Management, Vol. 65, pp. 217-227.

\section{Corresponding author}

Federico Adrodegari can be contacted at: federico.adrodegari@unibs.it

For instructions on how to order reprints of this article, please visit our website:

www.emeraldgrouppublishing.com/licensing/reprints.htm

Or contact us for further details: permissions@emeraldinsight.com 